\title{
Thymic Tumor cM1b TNM Finding v8
}

National Cancer Institute

\section{Source}

National Cancer Institute. Thymic Tumor CM1b TNM Finding v8. NCI Thesaurus. Code C136299.

Thymic tumor with pulmonary intraparenchymal nodule or distant organ metastasis.

(from AJCC 8th Ed.) 